\title{
Efektifitas Media Cerita Bergambar (CERGAM) terhadap Pengetahuan, Sikap dan Tindakan Siswa PAUD/TK
}

\author{
Tetes Wahyu Witradharma ${ }^{1}$, Jumiyati ${ }^{2}$ \\ Jurusan Gizi, Politeknik Kesehatan Kemenkes Bengkulu, Indonesia \\ Email: abie81alief08fathur11@gmail.com
}

\begin{abstract}
The Effectiveness of Drawing Story Media to Knowledge, Attitude, and Behavior of Kindergarten Students. The low consumption of vegetables and fruits in the community requires an Eat Vegetables and Fruit Campaign as an effort to reach the Nutrition Conscious Family, especially in school-age children and adolescents as the nation's successors. The research objective was to determine the effectiveness of drawing story media to knowledge, attitude, and behavior of kindergarten. The study used a quasi-experiment study, with a non-randomized control group pre-test - post-test design. Research location in Puskesmas Padang Serai Bengkulu City. The population is kindergarten students. Sampling using the non-probability method with purposive sampling technique totaling 60 samples. Data were analyzed by univariate, bivariate dependent ttest/Wilcoxon test, independent t-test/Mann Whitney and covariance analysis test. The results showed that there were differences in knowledge, attitudes, and behavior in the treatment and control groups, furthermore the drawing story media was effective to knowledge, attitude, and behavior of kindergarten students. Educate by using drawing story media continuously as an effort to increase the knowledge, attitude, and behavior of kindergarten students. Elaborate drawing story media with more interesting storylines and colorful images.
\end{abstract}

Keywords: Attitudes, Behavior, Drawing story media, Kindergarten students Knowledge

\begin{abstract}
Abstrak: Efektifitas Media Cerita Bergambar (CERGAM) terhadap Pengetahuan, Sikap dan Tindakan Siswa PAUD/TK. Rendahnya konsumsi sayur dan buah di masyarakat, diperlukan adanya Kampanye Makan Sayur dan Buah dalam upaya mencapai Keluarga Sadar Gizi (KADARZI) terutama pada anak usia sekolah dan remaja sebagai penerus bangsa. Tujuan penelitian untuk mengukur efektifitas media cerita bergambar (CERGAM) terhadap pengetahuan, sikap dan tindakan siswa PAUD/TK. Penelitian menggunakan desain penelitian eksperimen semu (quasi experiment study), dengan rancangan non randomized control group pre-test post-test test design. Lokasi penelitian di wilayah kerja Puskesmas Padang Serai Kota Bengkulu pada bulan Apri-Juli 2018. Populasi adalah siswa PAUD/TK. Pengambilan sampel menggunakan cara non probability dengan teknik purposive sampling berjumlah 60 orang. Data dianalisis univariat, bivariat t-test dependen/wilcoxon test dan t-test independen/mann whitney serta analisis kovarian. Hasil penelitian menunjukkan terdapat perbedaan pengetahuan, sikap dan tindakan pada kelompok perlakuan dan kontrol, lebih lanjut media CERGAM efektif terhadap pengetahuan, sikap dan tindakan siswa PAUD/TK. Melakukan edukasi menggunakan media CERGAM Pangeran Nutrin dan Prajurit Buah Sayur secara berkesinambungan sebagai upaya meningkatkan pengetahuan, sikap dan tindakan siswa PAUD/TK. Mengembangkan media CERGAM lebih banyak lagi dengan alur cerita dan gambar yang lebih menarik dan berwarna.
\end{abstract}

Kata kunci: Sikap, Tindakan, CERGAM, Siswa PAUD/TK, Pengetahuan

\section{PENDAHULUAN}

Konsumsi sayur dan buah pada anak masih sangat minim dan masih banyak yang belum sesuai dengan rekomendasi. Menurut Pedoman Gizi Seimbang (2014), bagi anak balita dan anak usia sekolah dianjurkan untuk mengkonsumsi sayuran dan buah-buahan sebanyak 300-400gr yang terdiri dari 250 gram sayur (setara dengan 2,5 porsi atau 2,5 gelas sayur setelah dimasak dan ditiriskan) dan 150gr buah (setara dengan 3 buah pisang ambon ukuran sedang atau 1,5 potong pepaya ukuran sedang atau 3 buah jeruk ukuran sedang) (Izawardy, 2014).

Kekurangan konsumsi sayur dan buah pada anak dapat menimbulkan berbagai penyakit di kemudian hari. Rendahnya konsumsi sayur dan buah ini berkaitan dengan meningkatnya risiko terjadinya penyakit kronik seperti penyakit jantung dan diabetes (Anwar, 2014). Anak yang 
mengkonsumsi sayur dan buah dalam jumlah tinggi pada masa kanak-kanaknya memiliki kesehatan yang lebih baik dan risiko untuk terkena penyakit kronik yang berkaitan dengan diet menjadi berkurang (Kemenkes RI, 2014).

Kekurangan sayur juga dapat memberikan dampak buruk pada mata, juga dapat menyebabkan anemia dengan gejala seperti lemah, letih, lesu, kurang konsentrasi dan malas pada anak. Konstipasi juga akan menjadi penyakit yang akan dialami bila anak kurang mengkonsumsi sayur dan buah (Yuliah, Adriyani Adam, 2017). Kurang mengkonsumsi sayur dan buah juga erat kaitannya dengan obesitas, dimana dengan rajin mengkonsumsi buah setiap kali waktu makan maka akan menghindari terjadinya kenaikan berat badan. Asupan sayur dan buah juga berperan penting dalam perkembangan mental dan fisik pada anak. Secara umum, anakanak yang tinggal di negara berkembang termasuk Indonesia lebih sulit mengonsumsi sayur dan buah dibandingkan dengan anak-anak di negara maju. Mereka justru akan menghindari makanan-makanan yang menyehatkan seperti sayur dan buah. Pada usia anak-anak, khususnya usia prasekolah terjadi perkembangan aktivitas jasmani, dan meningkatnya proses berpikir (Murni, 2017).

Dalam mengakses dan memilih makanan pada anak dipengaruhi oleh beberapa faktor, salah satunya adalah faktor lingkungan, baik itu lingkungan rumah maupun di luar rumah (Hermina \& Prihatini, 2016). Jika di dalam rumah, faktor yang paling berperan antara lain faktor orang tua yang termasuk di dalamnya pekerjaan, pendidikan, pendapatan, ketersediaan pangan faktor lingkungan di luar rumah seperti guru yang mengajar di sekolah, teman bermain serta iklan-iklan di media massa.

Berdasarkan survei yang telah dilakukan didapatkan sebanyak 71,9\% memiliki pola makan tidak baik dan hanya sebanyak $28,1 \%$ memiliki pola makan yang baik, khususnya sayur dan buah. Masih sangat rendahnya konsumsi sayur dan buah di masyarakat, diperlukan adanya kampanye "Makan Sayur dan Buah" dalam upaya mencapai Keluarga Sadar Gizi (KADARZI) terutama pada anak usia sekolah dan remaja sebagai penerus bangsa. Untuk meningkatkan edukasi gizi mengenai manfaat buah dan sayur serta cara memperkenalkan dan meningkatkan kesukaan anak terhadap buah dan sayur maka diperlukan upaya untuk mewujudkan hal itu. Berdasarkan latar belakang di atas, penulis tertarik menjadikan "efektifitas media cerita bergambar (CERGAM) terhadap pengetahuan, sikap dan tindakan siswa
PAUD/TK di wilayah kerja Puskesmas Padang Serai Kota Bengkulu Tahun 2018" sebagai judul penelitian.

\section{METODE}

Penelitian ini menggunakan desain penelitian eksperimen semu (quasi experiment study), dengan rancangan non randomized control group pre-test post-test test design yang bertujuan untuk mengetahui kemungkinan hubungan sebab akibat dengan mengintervensi atau memberikan perlakuan kepada satu atau lebih kelompok eksperimen, kemudian hasil (akibat) dari intervensi tersebut dibandingkan dengan kelompok yang tidak dikenakan perlakuan (kelompok kontrol). Penelitian dilakukan di wilayah kerja Puskesmas Padang Serai Kota Bengkulu pada April-Juli 2018. Sampel pada masing-masing kelompok perlakuan yaitu 30 orang yang diberikan penyuluhan dengan media cergam dan 30 orang kelompok kontrol yang tanpa diberikan media. Total sampel seluruhnya adalah 60 orang responden.

Pengambilan sampel menggunakan cara non probability dan sampel diambil dengan teknik purposive sampling, adalah suatu teknik penetapan sampel dengan cara memilih sampel di antara populasi sesuai kriteria peneliti dengan kriteria inklusi seperti: responden bersedia menjadi sampel, datang pada saat penyuluhan, berusia 4-5 tahun dan berdomisili di wilayah kerja Puskesmas Padang Serai Kota Bengkulu dan kriteria ekslusi yaitu menderita penyakit kronis pada saat penelitian. Data primer dikumpulkan dengan wawancara kepada orang tua siswa PAUD/TK di wilayah kerja Puskesmas Padang Serai Kota Bengkulu dengan menggunakan kuesioner penelitian yang berisi pengetahuan, sikap dan tindakan dengan menggunakan kuesioner modifikasi. Data sekunder yaitu data tentang kondisi PAUD/TK yang diperoleh dari pihak sekolah di wilayah kerja Puskesmas Padang Serai Kota Bengkulu Kota Bengkulu berupa nama, jumlah dan kelas dalam bentuk absensi.

Analisis univariat merupakan analisis yang dilakukan terhadap tiap variabel dalam hasil penelitian. Analisis mendeskripsikan karakteristik setiap variabel penelitian. Pada umumnya dalam analisis ini hanya menghasilkan distribusi dan persentase dari tiap variabel. Variabel yang akan dilakukan analisis univariat dalam penelitian ini adalah perilaku meliputi pengetahuan, sikap, dan tindakan. Adapun variabel perancu meliputi usia dan pekerjaan. Hasil analisis univariat akan 
diketahui gambaran distribusi dan frekuensi setiap variabel.

Analisis bivariat yang dilakukan terhadap dua variabel yang diduga berhubungan atau berkorelasi. Data yang diperoleh kemudian diolah, dianalisis dalam suatu pembahasan dan disajikan dalam bentuk tabel. Sebelum melakukan uji bivariat dilakukan terlebih dahulu uji normalitas terhadap hasil perilaku pretestposttest pada kelompok perlakuan dengan menggunakan uji Kolmogorof Smirnof. Penelitian ini menggunakan 2 uji yaitu $t$-test dependen/wilcoxon test dan t-test independen/mann whitney test. $\mathrm{Uji}$ t-test dependen/wilcoxon test dilakukan untuk mengetahui ada atau tidaknya perbedaan pengetahuan, sikap, tindakan setelah setelah diberikan edukasi gizi oleh guru PAUD/TK menggunakan media cerita bergambar (CERGAM). Sedangkan analisis kovarian digunakan untuk menguji efektifitas media CERGAM bagi siswa PAUD/TK terhadap perubahan pengetahuan, sikap, tindakan, pola konsumsi sayuran dan buah siswa PAUD/TK di wilayah kerja Puskesmas Padang Serai Kota Bengkulu Tahun 2018.

Penelitian ini telah mendapatkan persetujuan etik penelitian dari Komisi Etik Penelitian Kesehatan Poltekkes Kemenkes Bengkulu No.DM.01.04/84/3/VI/2018.

\section{HASIL}

\section{Karakteristik Responden}

Tabel 1. Karakteristik Responden Kelompok Perlakuan dan Kontrol

\begin{tabular}{|c|c|c|c|c|c|}
\hline \multirow{2}{*}{$\begin{array}{c}\text { Karakteristik } \\
\text { Responden }\end{array}$} & \multicolumn{2}{|c|}{ Perlakuan } & \multicolumn{2}{|c|}{ Kontrol } & \multirow{2}{*}{ p-value } \\
\hline & f & $\%$ & f & $\%$ & \\
\hline \multicolumn{6}{|l|}{ Usia Ibu } \\
\hline$\leq 30$ Tahun & 9 & 50,0 & 9 & 50,0 & 1,000 \\
\hline$>30$ Tahun & 21 & 50,0 & 21 & 50,0 & \\
\hline \multicolumn{6}{|l|}{ Usia Ayah } \\
\hline$\leq 35$ Tahun & 14 & 60,9 & 9 & 39,1 & 0,288 \\
\hline$>35$ Tahun & 16 & 43,2 & 21 & 56,8 & \\
\hline \multicolumn{6}{|l|}{ Usia Anak } \\
\hline Usia 6 Tahun & 16 & 47,1 & 18 & 52,9 & 0,795 \\
\hline Usia 5 Tahun & 14 & 53,8 & 12 & 46,2 & \\
\hline \multicolumn{6}{|l|}{ Pekerjaan Ibu } \\
\hline Tidak Bekerja & 28 & 53,8 & 24 & 46,2 & 0,121 \\
\hline Bekerja & 2 & 25,0 & 6 & 75,0 & \\
\hline \multicolumn{6}{|l|}{ Pekerjaan Ayah } \\
\hline Swasta & 23 & 48,9 & 24 & 51,1 & 0,754 \\
\hline Buruh & 7 & 53,8 & 6 & 46,2 & \\
\hline
\end{tabular}

Distribusi frekuensi responden berdasarkan usia ibu pada kelompok perlakuan dan kelompok kontrol paling banyak adalah diatas 30 tahun yaitu 21 orang $(50,0 \%)$. Sedangkan untuk distribusi pekerjaan pekerjaan ibu responden pada kelompok perlakuan dan kontrol paling banyak adalah tidak bekerja yaitu $28(53,8 \%)$ dan $24(46,2 \%)$.

Sebagian besar dari kelompok perlakuan usia ayah >35 tahun adalah $16(43,2 \%)$, begitu juga pada kelompok kontrol didapatkan sebagian besar usia ayah >35 tahun adalah $21(56,8 \%)$. Sedangkan untuk distribusi pekerjaan ayah responden pada kelompok perlakuan dan kontrol paling banyak adalah swasta yaitu $23(48,9 \%)$ dan $24(51,1 \%)$. Untuk usia anak PAUD pada kelompok perlakuan dan kontrol sebagian besar adalah usia 6 tahun yaitu $16(47,1 \%)$ dan 18 $(52,9 \%)$

Hasil uji statistik usia ibu dan ayah, pekerjaan ibu dan ayah serta usia anak PAUD/TK diperoleh nilai $p>0,05$ maka dapat disimpulkan tidak ada perbedaan usia (ayah, ibu anak PAUD) dan pekerjaan antara kelompok perlakuan dengan kelompok kontrol.

\section{Deskripsi Pengetahuan, Sikap dan Tindakan Sebelum dan Sesudah Perlakuan}

Berdasarkan hasil uji statistik pengetahuan, tindakan, pola konsumsi sayur dan buah antara kelompok perlakuan dan kelompok kontrol sebelum perlakuan menunjukkan tidak ada perbedaan, kecuali sikap seperti yang tertera pada tabel 2. 
Tabel 2. Deskripsi Tingkat Pengetahuan, Sikap, Tindakan, Pola Konsumsi Sayuran dan Buah Sebelum Perlakuan pada Masing-Masing Kelompok

\begin{tabular}{|c|c|c|c|c|c|c|c|}
\hline \multirow{3}{*}{ Variabel } & \multicolumn{7}{|c|}{ Kelompok } \\
\hline & \multicolumn{3}{|c|}{ Perlakuan } & \multicolumn{4}{|c|}{ Kontrol } \\
\hline & Min & $\operatorname{Max}$ & Mean \pm SD & Min & $\operatorname{Max}$ & Mean \pm SD & $p$ \\
\hline Pengetahuan & 4,0 & 8,0 & $6,83 \pm 1,01$ & 1,0 & 8,0 & $6,13 \pm 1,61$ & 0,05 \\
\hline Sikap & 5,0 & 10,0 & $7,93 \pm 1,14$ & 3,0 & 9,0 & $6,80 \pm 1,47$ & 0,02 \\
\hline Tindakan & 21,0 & 47,0 & $35,4 \pm 4,87$ & 12 & 42,0 & $29,4 \pm 6,62$ & 0,19 \\
\hline $\begin{array}{l}\text { Pola } \quad \text { Konsumsi } \\
\text { Sayuran }\end{array}$ & 1,5 & 20,3 & $19,1 \pm 4,65$ & 0,54 & 34,6 & $12,5 \pm 8,71$ & 0,201 \\
\hline $\begin{array}{l}\text { Pola } \quad \text { Konsumsi } \\
\text { Buah }\end{array}$ & 2,6 & 20,3 & $8,5 \pm 4,24$ & 0,00 & 26,8 & $8,7 \pm 7,24$ & 0,891 \\
\hline
\end{tabular}

Tabel 2 menunjukan bahwa rata-rata tingkat pengetahuan yang diberi perlakuan adalah 6,83 dengan standar deviasi 1,01, kelompok kontrol rata-rata tingkat pengetahuannya 6,13 dengan standar deviasi 1,61. Rata-rata sikap yang diberi perlakuan adalah 7,93 dengan standar deviasi 1,14, sikap kelompok kontrol 6,80 dengan standar deviasi 1,47. Rata-rata tindakan yang diberi perlakuan adalah 35,4 dengan standar deviasi 4,87, tindakan pada kelompok kontrol yaitu 29,4 dengan standar deviasi 6,62. Rata-rata pola konsumsi sayuran yang diberi perlakuan adalah 19,1 dengan standar deviasi 4,65, pola konsumsi sayuran pada kelompok kontrol yaitu 12,5 dengan standar deviasi 8,71. Rata-rata pola konsumsi buah yang diberi perlakuan adalah 8,5 dengan standar deviasi 4,24, pola konsumsi buah pada kelompok kontrol yaitu 8,7 dengan standar deviasi 7,24.

Hasil uji statistik didapatkan nilai pengetahuan $(p=0,05)$, sikap $(p=0,02) \quad$ dan praktek $(p=0,19)$, artinya baik pada kelompok yang diberi perlakuan maupun kelompok tanpa perlakuan mempunyai pengetahuan, tindakan, pola konsumsi sayur dan buah (kecuali sikap) yang sama sebelum dilakuan penelitian $(p>0,05)$.

Berdasarkan hasil uji statistik pengetahuan, sikap, tindakan, antara kelompok perlakuan dan kelompok kontrol sesudah perlakuan menunjukkan ada perbedaan, kecuali pola konsumsi sayur dan buah seperti yang tertera pada tabel 3.

Tabel 3. Deskripsi Tingkat Pengetahuan, Sikap dan Tindakan Sesudah Perlakuan pada MasingMasing Kelompok

\begin{tabular}{|c|c|c|c|c|c|c|c|}
\hline \multirow{3}{*}{ Variabel } & \multicolumn{7}{|c|}{ Kelompok } \\
\hline & \multicolumn{3}{|c|}{ Perlakuan } & \multicolumn{4}{|c|}{ Kontrol } \\
\hline & Min & $\operatorname{Max}$ & Mean \pm SD & Min & $\operatorname{Max}$ & Mean士 SD & $p$ \\
\hline Pengetahuan & 6 & 8 & $7,56 \pm 0,62$ & 2 & 8 & $6,23 \pm 1,45$ & 0,001 \\
\hline Sikap & 5 & 10 & $8,43 \pm 1,45$ & 2 & 9 & $7,20 \pm 1,78$ & 0,005 \\
\hline Tindakan & 27 & 47 & $35,4 \pm 4,87$ & 16 & 46 & $31,7 \pm 6,62$ & 0,017 \\
\hline Pola Konsumsi Sayuran & 2,7 & 34,1 & $16,6 \pm 7,81$ & 4,61 & 44,2 & $15,2 \pm 10,44$ & 0,552 \\
\hline Pola Konsumsi Buah & 2,7 & 34,1 & $16,6 \pm 7,81$ & 2,72 & 36,4 & $12, \overline{3} \pm 8,01$ & 0.311 \\
\hline
\end{tabular}

Rata-rata pengetahuan kelompok perlakuan dan kelompok kontrol mempunyai skor yang berbeda, lebih tinggi pada kelompok perlakuan yaitu 7,56 dengan standar deviasi 0,62 sedangkan skor nilai pengetahuan kelompok kontrol 6,23 dengan standar deviasi 1,45. Demikian juga median sikap pada kelompok perlakuan dan kontrol juga menunjukkan perbedaaan, dimana sikap post-test pada kelompok perlakuan yaitu 8,43 dengan standar deviasi 1,45, kelompok kontrol nilai sikap yaitu 7,20 dengan standar deviasi 1,78. Rata-rata tindakan pada kelompok perlakuan dan kelompok kontrol mempunyai skor yang berbeda, lebih tinggi pada kelompok perlakuan yaitu 35,4 dengan standar deviasi 4,87 sedangkan kelompok kontrol 31,7 dengan standar deviasi 6,62. Ratarata pola konsumsi sayuran menunjukkan skor yang juga berbeda, pada kelompok perlakuan yaitu 16,6 dengan standar deviasi 7,81 sedangkan kelompok kontrol 15,2 dengan standar deviasi 10,44 . Hasil yang sama juga ditunjukkan pada pola konsumsi buah dimana pada kelompok perlakuan yaitu 16,6 dengan standar deviasi 7,81 dan kelompok kontrol yaitu 12,3 dengan standar deviasi 8,01.

Hasil uji beda didapatkan nilai pengetahuan $\quad(p=0,001)$, sikap $\quad(p=0,005)$, tindakan $(p=0,07)$. Hal ini menujukkan perbedaan pada kelompok perlakuan dan kontrol. Adapun pola konsumsi sayuran $(p=0,552)$ dan pola konsumsi buah $(p=0,311)$. Hal ini menunjukkan 
tidak ada perbedaan pada kelompok dan kontrol. Meskipun demikian, tetap ada perbedaan pada skor rata-rata dan deviasi.

\section{Perbedaan Pengetahuan, Sikap dan Tindakan Sebelum dan Sesudah pada Kelompok Perlakuan dan Kelompok Kontrol}

Perbedaan nilai pengetahuan, sikap, tindakan pada kelompok perlakuan dan kelompok kontrol sebelum dan sesudah perlakuan dapat dilihat pada tabel 4 .

Tabel 4 . Perbedaan Pengetahuan, Sikap dan Tindakan Sebelum dan Sesudah pada MasingMasing Kelompok

\begin{tabular}{|c|c|c|c|c|c|c|}
\hline \multirow{4}{*}{ Variabel } & \multicolumn{6}{|c|}{ Kelompok } \\
\hline & \multicolumn{3}{|c|}{ Perlakuan } & \multicolumn{3}{|c|}{ Kontrol } \\
\hline & Sebelum & Sesudah & & Sebelum & Sesudah & \\
\hline & Mean \pm SD & Mean \pm SD & $p$ & Mean \pm SD & Mean \pm SD & $p$ \\
\hline Pengetahuan & $6,8 \pm 1,01$ & $7,5 \pm 0,62$ & 0,001 & $6,1 \pm 1,61$ & $6,2 \pm 1,45$ & 0,71 \\
\hline Sikap & $7,9 \pm 1,14$ & $8,4 \pm 1,45$ & 0,087 & $7,2 \pm 1,78$ & $7,2 \pm 1,78$ & 0,22 \\
\hline Tindakan & $31,5 \pm 5,55$ & $35,4 \pm 4,87$ & 0,001 & $29,4 \pm 6,96$ & $31,7 \pm 6,62$ & 0,058 \\
\hline Pola Konsumsi Sayuran & $10,2 \pm 4,65$ & $16,6 \pm 7,81$ & 0,001 & $12,5 \pm 8,71$ & $15,1 \pm 1.04$ & 0,056 \\
\hline Pola Konsumsi Buah & $8,5 \pm 4,24$ & $14,2 \pm 6,94$ & 0,001 & $8,7 \pm 7,24$ & $12,3 \pm 8,01$ & 0,057 \\
\hline
\end{tabular}

Tabel 4 menunjukkan rata-rata pengetahuan pada kelompok perlakuan sebelum perlakuan adalah 6,8 dengan standar deviasi 1,01 , pada pengukuran sesudah perlakuan didapatkan rata-rata pengetahuan adalah 7,5 dengan standar deviasi 0,62. Sedangkan median sikap pada kelompok perlakuan sebelum perlakuan adalah 7,9 dengan standar deviasi 1,14, pada pengukuran sesudah perlakuan didapatkan median sikap adalah 8,4 dengan standar deviasi 1,45. Tindakan sebelum perlakuan pada kelompok perlakuan adalah 31,5 dengan standar deviasi 5,55, pada pengukuran setelah perlakuan didapatkan rata-rata tindakan adalah 35,4 dengan standar deviasi 4,87. Sedangkan rata-rata pola konsumsi sayuran sebelum perlakuan yaitu 10,2 dengan standar deviasi 4,65 dan rata-rata setelah pengukuran yaitu 16,6 dengan standar deviasi 7,81 . Demikian juga rata-rata pola konsumsi buah sebelum perlakuan yaitu 8,5 dengan standar deviasi 4,24 dan rata-rata pola konsumsi buah setelah perlakuan 14,2 dengan standar deviasi 6,94 . Hasil uji statistik pengetahuan $(p=0,001)$, sikap $(p=0,087)$, tindakan $(p=0,001)$, pola konsumsi sayuran $(p=0,001)$ dan pola konsumsi buah $(p=0,001)$ didapatkan nilai $p<0,05$, maka dapat disimpulkan ada perbedaan yang signifikan pengetahuan, tindakan, pola konsumsi sayuran dan buah, kecuali sikap sebelum dan sesudah perlakuan pada kelompok perlakuan.

Tabel 4 menunjukkan rata-rata pengetahuan pre-test pada kelompok kontrol adalah 6,1 dengan standar deviasi 1,61, pada pengukuran didapatkan rata-rata pengetahuan post-test adalah 6,2 dengan standar deviasi 1,45.
Sikap kelompok kontrol menunjukkan median pre-test adalah 7,2 dengan standar deviasi 1,78, pada pengukuran post-test didapatkan rata-rata sikap adalah 7,2 dengan standar deviasi 1,78. Rata-rata tindakan pre-test adalah 29,4 dengan standar deviasi 6,96, pada pengukuran post-test didapatkan rata-rata tindakan adalah 31,7 dengan standar deviasi 6,62. Rata-rata pola konsumsi sayuran pada kelompok kontrol pre-test menunjukkan nilai 12,5 dengan standar deviasi 8,71 , pada pengukuran post-test didapatkan ratarata yaitu 15,1 dengan standar deviasi 1,04. Pola konsumsi buah kelompok kontrol menunjukkan rata-rata pre-test adalah 8,7 dengan standar deviasi 7,24, pada pengukuran post-test didapatkan rata-rata pola konsumsi buah adalah 12,3 dengan standar deviasi 8,01. Hasil uji statistik pengetahuan $(p=0,71)$, sikap $(p=0,22)$, tindakan $(p=0,058)$, pola konsumsi sayuran $(p=0,056)$ dan pola konsumsi buah $(p=0,057)$ didapatkan nilai $p>0,05$ maka dapat disimpulkan tidak ada perbedaan yang signifikan antara pretest dan post-test pengetahuan, sikap, tindakan, pola konsumsi sayuran dan buah pada kelompok kontrol walaupun terdapat perubahan.

\section{Perubahan Skor (Pengetahuan, Sikap dan Tindakan) pada Kedua Kelompok}

Penilaian perubahan skor pengetahuan, sikap dan praktek kader pada kedua kelompok dapat dilihat pada tabel 5 . 
Tabel 5. Perubahan Skor Pengetahuan, Sikap dan Tindakan Antara Kelompok Perlakuan dan Kelompok Kontrol

\begin{tabular}{ccccc}
\hline $\begin{array}{c}\text { Variabel dan } \\
\text { Kelompok }\end{array}$ & n & Mean & Median \pm SD & $\boldsymbol{p}$ \\
\hline $\begin{array}{c}\text { Pengetahuan } \\
\quad \text { Perlakuan }\end{array}$ & 30 & 0,93 & $1,00 \pm 0,86$ & 0,004 \\
$\quad$ Kontrol & 30 & 0,10 & $0,00 \pm 1,51$ & \\
\hline $\begin{array}{c}\text { Sikap } \\
\quad \text { Perlakuan }\end{array}$ & 30 & 0,50 & $2,50 \pm 1,73$ & 0,890 \\
$\quad$ Kontrol & 30 & 0,60 & $1,00 \pm 2,12$ & \\
\hline $\begin{array}{c}\text { Tindakan } \\
\quad \text { Perlakuan }\end{array}$ & 30 & 3,80 & $4,53 \pm 5,82$ & 0,604 \\
$\quad$ Kontrol & 30 & 2,50 & $3,00 \pm 6,57$ & \\
\hline $\begin{array}{l}\text { Pola Konsumsi } \\
\text { Sayuran }\end{array}$ & 30 & 6,42 & $4,53 \pm 7,65$ & 0,049 \\
$\quad \begin{array}{l}\text { Perlakuan } \\
\quad \text { Kontrol }\end{array}$ & 30 & 2,67 & $2,85 \pm 1,07$ & \\
\hline $\begin{array}{c}\text { Pola Konsumsi } \\
\text { Buah }\end{array}$ & 30 & 5,77 & $3,91 \pm 6,91$ & 0,119 \\
$\quad \begin{array}{l}\text { Perlakuan } \\
\quad \text { Kontrol }\end{array}$ & 30 & 3,58 & $2,00 \pm 8,53$ & \\
\hline
\end{tabular}

Hasil uji statistik menunjukkan bahwa untuk kelompok perlakuan peningkatan nilai pengetahuan adalah 1,00 dengan standar deviasi 0,86 , sedangkan untuk kelompok kontrol nilai median perubahan skor pengetahuan 0,00 dengan standar deviasi 1,51. Begitu juga untuk hasil sikap pada kelompok perlakuan yaitu 2,50 dengan standar deviasi 1,73, kelompok kontrol peningkatan nilai sikap adalah 1,00 dengan standar deviasi 2,12. Sedangkan untuk tindakan kelompok perlakuan menunjukkan adalah 4,53 dengan standar deviasi 5,82, untuk kelompok kontrol nilai median perubahan skor tindakan 3,00 dengan standar deviasi 6,57. Adapun hasil pola konsumsi sayuran pada kelompok perlakuan yaitu 4,53 dengan standar deviasi 7,65, kelompok kontrol peningkatan nilai sikap adalah 2,85 dengan standar deviasi 1,07. Sedangkan untuk pola konsumsi buah kelompok perlakuan menunjukkan adalah 3,91 dengan standar deviasi 6,91, untuk kelompok kontrol nilai median perubahan skor tindakan 2,00 dengan standar deviasi 8,53.

Hasil uji beda pengetahuan $(p=0,004)$ dan pola konsumsi sayuran $(p=0,049)$, didapatkan nilai $p<0,05$, maka dapat disimpulkan ada perubahan skor yang signifikan pengetahuan dan pola konsumsi sayuran antara kelompok perlakuan dengan kelompok kontrol. Sedangkan sikap $(p=0,890)$, tindakan $(p=0,604)$, dan pola konsumsi buah $(p=0,119)$, didapatkan nilai $p>0,05$, maka dapat disimpulkan tidak ada perubahan skor yang signifikan sikap, tindakan dan pola konsumsi buah antara kelompok perlakuan dengan kelompok kontrol.

Kesimpulan yang bisa diambil terjadi perbedaan yang bermakna pada pengetahuan dan pola konsumsi sayuran tetapi tidak menunjukkan perbedaan pada sikap, tindakan dan pola konsumsi buah pada kedua kelompok sebelum dan sesudah perlakuan. Lebih lanjut, secara keseluruhan perubahan yang terjadi pada kelompok perlakuan lebih besar dibandingkan pada kelompok kontrol.

Model Akhir Analisis Kovarian (Pengetahuan, Sikap, Tindakan, Pola Konsumsi Sayuran dan Buah) pada Kedua Kelompok

Dalam penelitian ini dilakukan pengujian efektifitas media CERGAM bagi siswa PAUD terhadap perubahan pengetahuan, sikap, tindakan, pola konsumsi sayuran dan buah. Sebelum analisis kovarian dilakukan, harus memenuhi syarat yaitu ada hubungan linier antara kovarian dengan variabel dependen dan kemiringan (slope) garis regresi antar kelompok harus sama. Hubungan linier antara kovarian dengan variabel dependen dibuktikan dengan analisis korelasi dimana jika ada korelasi yang signifikan antara kovarian dan variabel dependen maka dapat dilanjutkan ke analisis kovarian. Kesamaan kemiringan garis regresi antar kelompok dibuktikan dengan tidak adanya interaksi antara kovarian dengan perlakuan. Hasil analisis korelasi terhadap kovarian dengan variabel dependen menunjukkan terdapat korelasi yang signifikan pada variabel pengetahuan, sikap, tindakan, pola konsumsi sayuran dan buah. Model akhir analisis kovarian dapat dilihat pada tabel 6 .

Tabel 6. Model Akhir Analisis Kovarian

\begin{tabular}{lrrrrr}
\hline \multirow{2}{*}{ Variabel } & \multicolumn{2}{c}{ Kelompok } & \multirow{2}{*}{ F } & \multirow{2}{*}{$\boldsymbol{p}^{\mathfrak{1}}$} & $\begin{array}{c}\text { Partial Eta } \\
\text { squared }\end{array}$ \\
\cline { 2 - 3 } & \multicolumn{1}{c}{ Perlakuan } & \multicolumn{1}{c}{ Kontrol } & & \multicolumn{1}{c}{ squar } \\
\hline Pengetahuan & $7,56 \pm 0,62$ & $6,23 \pm 1,45$ & 19,13 & 0,001 & 0,402 \\
Sikap & $8,4 \pm 1,45$ & $7,20 \pm 1,78$ & 9,721 & 0,001 & 0,254 \\
Tindakan & $35,46 \pm 4,87$ & $31,76 \pm 6,62$ & 12,46 & 0,001 & 0,304 \\
Pola Konsumsi Sayuran & $16,60 \pm 7,81$ & $15,17 \pm 10,44$ & 4,49 & 0,015 & 0,136 \\
Pola Konsumsi Buah & $14,28 \pm 6,94$ & $12,30 \pm 8,01$ & 4,51 & 0,015 & 0,137 \\
\hline
\end{tabular}

$£$ General Linear Model dikontrol oleh hasil pemeriksaan awal masing-masing variabel 
Analisis kovarian menunjukkan rerata hasil pemeriksaan akhir pada variabel pengetahuan, sikap, tindakan, pola konsumsi sayuran dan buah lebih tinggi pada kelompok perlakuan dibandingkan kelompok kontrol. Selanjutnya, terdapat perbedaan hasil akhir pada variabel pengetahuan, sikap, tindakan, pola konsumsi sayuran dan buah antara kelompok perlakuan dan kelompok kontrol setelah diberikan media CERGAM bagi siswa PAUD $(p<0,05)$. Sumbangan efektifitas pemberian media CERGAM bagi siswa PAUD terhadap perubahan hasil pada masing-masing variabel yakni $40,2 \%$ untuk pengetahuan; $25,4 \%$ untuk sikap; 30,4\% untuk tindakan; $13,6 \%$ untuk pola konsumsi sayuran dan $13,7 \%$ untuk pola konsumsi buah.

\section{PEMBAHASAN}

\section{Karakteristik Keluarga Siswa PAUD/TK}

Dalam penelitian ini karakteristik responden perlakuan dan kontrol yang akan dilihat adalah usia ibu, ayah dan anak serta pekerjaan ibu dan ayah. Hasil penelitian menunjukkan bahwa tidak ada perbedaan usia ibu, ayah dan anak pada kelompok perlakuan dan kontrol. Rata-rata umur ibu pada kelompok perlakuan dan kontrol tergolong pada rentang umur dewasa awal. Rata-rata umur ayah pada kelompok perlakuan dan kontrol tergolong pada rentang umur dewasa akhir. Meskipun demikian, juga ditemukan umur ayah pada kelompok perlakuan dan kontrol tergolong pada rentang umur lansia awal dan lansia akhir serta dan umur ibu yang tergolong pada rentang umur remaja akhir. Hal ini menunjukkan bahwa karakteristik keluarga siswa PAUD/TK secara keseluruhan telah homogen.

Demikian juga tidak ada perbedaan pekerjaan ibu dan ayah pada kelompok perlakuan dan kontrol. Hal ini menunjukkan bahwa karakteristik pekerjaan ibu dan ayah telah homogen. Karakteristik keluarga yang homogen diperlukan sebelum memulai penelitian intervensi sehingga setiap kelompok yang ada, baik kelompok perlakuan maupun kelompok kontrol di dalam penelitian tersebut memiliki kriteria sampel yang relatif sama satu dengan yang lainnya.

\section{Gambaran Pengetahuan, Sikap, dan Tindakan Siswa PAUD/TK}

Penelitian ini menunjukkan ada perbedaan pengetahuan pada kelompok perlakuan dan kontrol. Pada pre-test menggambarkan nilai rerata yang tidak jauh berbeda antara kelompok perlakuan dan kontrol begitu juga dengan nilai deviasi yang hampir sama. Tetapi pada post-test, ternyata menunjukkan penurunan nilai rerata pada kelompok kontrol dibanding kelompok perlakuan dengan sebaran deviasi yang cukup lebar. Hal ini menjelaskan bahwa penggunaan media CERGAM efektif untuk meningkatkan pengetahuan pada kelompok perlakuan dibandingkan pada kelompok kontrol.

Penelitian ini menunjukkan bahwa ada perbedaan pengetahuan pre-test dan post-test pada kelompok perlakuan. Hal ini menjelaskan bahwa media CERGAM berpengaruh pada pengetahuan siswa PAUD/TK. Penggunaan media CERGAM menjadi sarana yang efektif untuk melakukan perubahan pada pengetahuan. Penelitian ini juga menunjukkan nilai pengetahuan terendah pada saat pre-test mengalami peningkatan pada saat post-test. Sedangkan nilai pengetahuan tertinggi berada pada level yang sama. Meskipun demikian, analisis statistik menggambarkan penurunan deviasi pre-test post-test pada kelompok perlakuan yang diikuti dengan peningkatan nilai rata-rata pre-test post-test yang cukup signifikan. Hal ini menjelaskan terjadi peningkatan pengetahuan pada hampir semua siswa pada kelompok perlakuan, yang membuktikan media CERGAM efektif untuk meningkatkan pengetahuan dan menjadikan siswa pada kelompok perlakuan memiliki pengetahuan yang hampir sama dan tidak jauh berbeda satu sama lain

Selanjutnya pada kelompok kontrol menunjukkan tidak ada perbedaan pengetahuan pre-test dan post-test. Pada kelompok ini, nilai terendah pre-test mengalami peningkatan pada saat post-test walaupun nilainya masih di bawah kelompok perlakuan. Demikian pula, nilai tertinggi pre-test post-test yang sama dengan kelompok kontrol. Di lain pihak, kelompok kontrol memiliki nilai rerata pre-test yang mengalami penurunan pada saat pre-test dan sebaliknya mengalami peningkatkan deviasi pada saat post-test. Hal ini menunjukkan bahwa edukasi tanpa menggunakan media CERGAM membuat kelompok kontrol tidak dapat optimal menerima informasi secara menyeluruh dan mempertahankan informasi dalam jangka waktu yang lama bahkan cenderung terjadi lost information pada akhir penelitian.

Pengetahuan merupakan aspek kognitif yang memiliki peran penting dalam membentuk tindakan seseorang. Pengetahuan seseorang terbentuk dari rasa ingin tahu terhadap sesuatu 
yang diperoleh melalui panca indera manusia, baik melalui penglihatan, pendengaran, penciuman, perasa, maupun peraba. Jumlah alat indera yang digunakan menentukan besarnya daya serap dan pemahaman seseorang terhadap pengetahuan baru (Notoatmodjo, 2010). Belajar melalui bermain dinilai lebih efektif dalam menyampaikan pengetahuan baru karena dapat memberikan kesempatan bagi anak untuk bereksplorasi dalam menemukan, mengekspresi, serta berkreasi secara menyenangkan. Oleh karena itu, penggunaan media edukasi cerita bergambar dapat menjadi salah satu referensi dalam meningkatkan pengetahuan. CERGAM menampilkan alur cerita yang menarik, lugas dan mudah dipahami serta gambar-gambar yang penuh warna, sehingga siswa yang membaca akan langsung masuk ke dalam alur cerita.

Menurut Notoatmodjo (2007), alat bantu atau peraga atau media pendidikan adalah alatalat yang digunakan oleh pendidik dalam menyampaikan bahan pendidikan atau pengajarannya. Keuntungan penggunaan media adalah dapat menimbulkan minat sarana pendidikan, mencapai sasaran yang lebih banyak, membantu dalam mengatasi banyak hambatan dan pemahaman, merangsang sasaran pendidikan untuk meneruskan pesan-pesan yang diterima kepada orang lain, mempermudah penyampaian bahan pendidikan atau informasi oleh pendidik, mempermudah penerimaan informasi oleh sasaran pendidikan, mendorong keinginan orang untuk mengetahui, kemudian lebih mendalami dan akhirnya mendapatkan pengertian yang lebih baik, membantu menegakan pengertian yang diperoleh.

Penelitian Yuliana, dkk (2015) menunjukkan hasil bahwa terdapat perbedaan yang signifikan dengan p-value 0,001 antara tingkat pengetahuan sebelum dan sesudah pendidikan kesehatan. Sejalan dengan teori Edgar Dale (1964) dalam Wibowo dan Suryani (2013) menyatakan bahwa membaca akan mengingat $10 \%$, mendengar akan mengingat $20 \%$, melihat akan mengingat 30\%, mendengar dan melihat akan mengingat $50 \%$. Jadi, media CERGAM melibatkan dua indra yaitu penglihatan dan pendengaran akan dapat mengingat 50\%, dibandingkan kelompok kontrol yang hanya mendapatkan penyuluhan.

Penelitian ini juga menunjukkan ada perbedaan sikap pada kelompok perlakuan dan kontrol. Data ini menggambarkan nilai rerata yang lebih besar pada kelompok perlakuan dibandingkan pada kelompok kontrol dengan nilai deviasi yang lebih kecil pada kelompok perlakuan dibandingkan pada kelompok kontrol.
Hal ini semakin membuktikan bahwa terdapat perubahan sikap yang lebih besar dan merata pada kelompok perlakuan dibandingkan kelompok kontrol.

Penelitian ini menunjukkan bahwa tidak ada perbedaan sikap pre-test dan post-test pada kelompok perlakuan. Meskipun demikian, ditemukan peningkatan nilai rerata pre-test posttest pada kelompok ini walaupun tidak terjadi pada sebaran deviasi. Hal ini membuktikan bahwa tetap ada perubahan sikap yang terjadi pada kelompok ini dengan sebaran yang lebih luas dari pada sebelumnya dan pada beberapa sampel terdapat perubahan yang cukup siginifikan.

Demikian pula pada kelompok kontrol menunjukkan tidak ada perbedaan sikap pre-test dan post-test. Data menunjukkan terjadi penurunan pada nilai terendah tetapi tidak mengalami peningkatan pada nilai tertinggi. Hasil penelitian ini juga menunjukkan hasil yang relatif sama pada nilai rerata dan sebaran deviasi. Hal ini membuktikan bahwa sikap pada sebagian kelompok kontrol cenderung mengalami penurunan yang cukup besar selama penelitian meskipun juga ditemukan pada beberapa sampel sikap yang tidak berubah dan sebagian yang lain mengalami peningkatan tetapi tidak signifikan.

Sejalan dengan penelitian sebelumnya Ferwanda dan Muniroh (2017) juga menunjukkan adanya perbedaan sikap $(p=0,038)$ yang signifikan antara sebelum dan setelah diberikan pendidikan gizi melalui media buku edukatif berbasis games. Hasil penelitian Santi, dkk (2014) menunjukkan sikap responden setelah diberikan pendidikan kesehatan meningkat signifikan dengan nilai $p$-value $0,000(p<0,05)$ dibandingkan sebelum diberikan pendidikan kesehatan menggunakan media audio visual.

Penelitian ini juga menunjukkan ada perbedaan tindakan pada kelompok perlakuan dan kontrol. Perbedaan juga terlihat pada nilai terendah dan nilai tertinggi, dimana lebih tinggi pada kelompok perlakuan dibandingkan kelompok kontrol yang berbanding terbalik dengan besaran deviasi lebih kecil pada kelompok perlakuan dibandingkan kelompok kontrol.

Penelitian ini menunjukkan bahwa ada perbedaan tindakan pre-test dan post-test pada kelompok perlakuan. Hasil ini didukung dengan adanya peningkatan nilai terendah dan tertinggi serta rerata pada kelompok perlakuan disertai deviasi yang semakin kecil. Hal ini membuktikan telah terjadi perubahan tindakan pada kelompok perlakuan. 
Sedangkan pada kelompok kontrol menunjukkan tidak ada perbedaan tindakan pretest dan post-test pada kelompok kontrol. Pada kelompok ini, nilai terendah pre-test mengalami penurunan pada saat post-test dan nilainya masih di bawah kelompok perlakuan. Demikian pula, nilai tertinggi pre-test mengalami penurunan pada saat post-test. Di lain pihak, kelompok kontrol memiliki nilai rerata pre-test yang mengalami penurunan pada saat post-test dan sebaliknya mengalami peningkatkan deviasi pada saat post-test. Hal ini menunjukkan bahwa edukasi tanpa menggunakan media CERGAM membuat kelompok kontrol tidak dapat menerima informasi secara menyeluruh dan tidak dapat mempertahankan informasi dalam jangka waktu yang lama.

Penelitian ini juga melihat realisasi dari tindakan yaitu dengan mengamati pola makan sayuran dan buah, dimana tidak ada perbedaan pola konsumsi sayuran dan buah pada pada kelompok perlakuan dan kontrol. Meskipun demikian, perbedaan dapat terlihat pada nilai terendah dan nilai tertinggi, dimana lebih tinggi pada kelompok perlakuan dibandingkan kelompok kontrol yang berbanding terbalik dengan besaran deviasi lebih kecil pada kelompok perlakuan dibandingkan kelompok kontrol.

Berbeda dengan hasil penelitian yang secara nyata membandingkan antara kelompok perlakuan dan kontrol. Hasil penelitian yang membandingkan pola konsumsi sayuran dan buah pre-test dan post-test menunjukkan ada perbedaan pola konsumsi sayuran dan buah pada kelompok perlakuan. Sedangkan pada kelompok kontrol menunjukkan tidak ada perbedaan pola konsumsi sayuran dan buah. Hal ini menjelaskan bahwa penggunaan media CERGAM dapat untuk meningkatkan pengetahuan pada kelompok perlakuan dibandingkan pada kelompok kontrol.

Menurut Notoatmodjo (2007), adanya suatu tindakan seperti pendidikan kesehatan akan menjadi stimulus rangsangan dalam diri seseorang, kemudian akan terjadi proses stimulus yang memungkinkan seseorang untuk mengambil suatu respon yang ada pada akhirnya melahirkan sikap tertutup yaitu tidak menanggapi tindakan tersebut dan juga sebagian orang melahirkan reaksi tingkah laku yang terbuka yaitu respon yang dapat menyikapi suatu tindakan baik tindakan negatif maupun tindakan positif.

\section{Efektifitas Media Cerita Bergambar (CERGAM) terhadap Pengetahuan, Sikap dan Tindakan Siswa PAUD/TK}

Hasil penelitian menunjukkan ada perbedaan yang bermakna secara statistik pada perubahan rerata pengetahuan dan pola konsumsi sayuran pada kelompok perlakuan dibandingkan kelompok kontrol. Hasil yang berbeda ditunjukkan pada variabel sikap, tindakan dan pola konsumsi buah, dimana tidak ada perbedaan yang bermakna secara statistik rerata pada kelompok perlakuan dibandingkan kelompok kontrol. Meskipun demikian, jika dilihat lebih lanjut akan nampak perubahan rerata pada kedua kelompok.

Untuk menguji efektifitas media CERGAM pada kelompok perlakuan dimana diharapkan memiliki perubahan maka dilakukan uji lanjutan. Hasil penelitian menunjukkan media CERGAM efektif terhadap pengetahuan, sikap, tindakan, pola konsumsi sayuran dan buah.

CERGAM merupakan salah satu media pendukung pendidikan kesehatan yang efektif dalam meningkatkan pengetahuan, sikap dan tindakan secara dini pada anak-anak. CERGAM dirancang sedemikian rupa agar dapat menggambarkan berbagai peran penting vitamin dan mineral bagi tubuh melalui tokoh-tokoh animasi yang mudah diterima dan dipahami. Anak-anak dapat dengan mudah mencerna pesanpesan penting yang disampaikan selama proses pendidikan kesehatan berlangsung, yang tergambar dari jawaban-jawaban singkat yang disampaikan pada saat tanya jawab selama proses dan akhir pendidikan kesehatan. Demikian juga ketika anak-anak diminta untuk melakukan pengulangan atau menceritakan kembali materi yang telah disampaikan dengan kalimat sederhana. Peningkatan pengetahuan responden tentang sayur dan buah dimungkinkan karena penggunakan metode ceramah serta media buku edukatif berbasis games mampu merangsang responden dalam memaksimalkan penggunaan alat indera pengelihatan dan pendengaran sehingga responden mampu menerima pengetahuan baru dengan baik (Ferwanda \& Muniroh, 2017).

\section{SIMPULAN}

a. Tidak ada perbedaan usia dan pekerjaan antara kelompok perlakuan dengan kelompok kontrol siswa PAUD/TK. 
b. Ada perbedaan pengetahuan, sikap dan tindakan pada kelompok perlakuan dan kontrol siswa PAUD/TK.

\section{DAFTAR PUSTAKA}

Anwar, R. (2014). Konsumsi Buah Dan Sayur Serta Konsumsi Susu Sebagai Faktor Risiko Terjadinya Hipertensi DI Puskesmas S. Parman Kota Banjarmasin. Jurnal Skala Kesehatan, 5(1).

Izawardy, D. (2014). Pedoman Gizi Seimbang. Jakarta: Kemenkes.

Ferwanda, A. F., \& Muniroh, L. (2017). Efektivitas Buku Edukatif Berbasis Games terhadap Perubahan Pengetahuan serta Sikap tentang Sayur dan Buah (Studi Di SDN Suko 1 Kabupaten Sidoarjo). Amerta Nutr, 389-397. https://doi.org/10.20473/amnt.v1.i4.2017.3 89-397

Hermina, \& Prihatini. (2016). Gambaran Konsumsi Sayur dan Buah Penduduk Indonesia dalam Konteks Gizi Seimbang: Analisis Lanjut Survei Konsumsi Makanan Individu (SKMI) 2014. Buletin Penelitian c. Media CERGAM efektif terhadap pengetahuan, sikap dan tindakan siswa PAUD/TK

Kesehatan, 44, 205-218.

Kemenkes RI. (2014). Info Datin Pusat Data dan Informasi Kementrian Kesehatan RI. Kemenkes RI, 109(1), 1-8. https://doi.org/10.1017/CBO97811074153 24.004

Murni. (2017). Perkembangan Fisik, Kognitif, dan Psikososial pada Masa Kanak-Kanak awal 2-6 tahun. Jurnal Ilmiah Islam Futura, III, 19-33.

Notoatmodjo. (2007). Pendidikan dan Perilaku Kesehatan. Jakarta: Rineka Cipta.

Notoatmodjo, S. (2010). Ilmu Perilaku Kesehatan. Jakarta: Rineka Cipta.

Yuliah, Adriyani Adam, M. H. (2017). Konsumsi Sayur dan Buah dengan Kejadian Obesitas Pada Remaja Di SMA Negeri 1 Mamuju Tahun 2016. Jurnal Kesehatan Manarang, 3(1), 3-6. 